\title{
Empowering Women's Economy by Improving Environment Skills in a Fisherman Community in Kepulauan Seribu, Jakarta
}

\author{
Ida Rosyidah \\ Departement of Sociology \\ Faculty of Social and Political Science \\ State Islamic University, Jakarta, Indonesia \\ idar.ihsan@gmail.com
}

\section{INTRODUCTION: GENDER GAP IN KEPULAUAN SERIBU}

Studies on the roles of government and private organizations in women's economic empowerment, especially in fisherman communities, have been widely conducted $[1][2][3][4][5]$. However, the study of the roles of community-based institutions in empowering women's economy through improving the environmental skill is still limited. Thus, this study aims to fulfill the gap. In addition, the study of women's economic empowerment mostly uses Gender Analysis Pathway theory, or Structural Functionalist theory [6][7][8][9]. Meanwhile, this study utilizes Nayla Kabeer's conception as its theoretical framework to discuss the empowerment of female members of Rural Conservation Extension Center (Sentra Penyuluh Konservasi Pedesaan, or SPKP) Samo-Samo in Kepulauan Seribu (literally translates to Thousand Islands).

Kepulauan Seribu is an administrative region of DKI Jakarta Province, with the lowest welfare compared to the other regions. The 2013 Central Bureau of Statistics indicates the number of poor people in Kepulauan Seribu reached $11.01 \%$, compared to $5.3 \%$ in North Jakarta and below $4 \%$ in other regions. Similarly, Human Development Index (HDI) of Kepulauan Seribu in 2015 was only 68.84 much lower than that of South Jakarta (83.37), East Jakarta (80.73), West Jakarta (79.72), Central Jakarta (79.69) and North Jakarta (78.30).

Most importantly, the social interaction explicitly deploys gender inequality in Kepulauan Seribu. Women are behind men in the education, health, and political sectors. In the education field, the enrollment rate of elementary school is higher for girls than boys (97\% compared to 93\%), but for middle school, the enrollment rate favors boys (89\%) far more than the girls $(81 \%)$, and likewise of high school level (boys 67\% and girls 60\%). In the labor force, there is a high number of the women population who hold status as housewives $(3,078)$.

Some factors that caused such statistics are the local patriarchal culture which subordinates women, the state policies that avoid women's interests, and gender biased religious interpretations. As a result, women actors have emerged in the hopes of changing their livelihoods and encouraging economic independence. These women work at the grassroots level and were recently endorsed by the government to establish an NGO called SPKP (Sentra Penyuluh Konservasi Pedesaan) Samo-samo.

\section{KABEER'S VIEWS ON EMPOWERMENT}

Various disciplines have widely defined the term empowerment. In one, Lincoln et al. [10] defines empowerment as the use of certain techniques to transform those without power into equitable positions. Rappaport [11] explains that empowerment is a mechanism to encourage community getting mastery in their concern. A more comprehensive definition of empowerment refers to Eyben, Cornwall et al. [12] that empowerment covers multidimensional aspects, and for change, requires all aspects of life such as social, political, economic, legal, and such; therefore providing opportunities to those marginalized to participate in the entire process of development.

According to Kabeer [13], a feminist from Bangladesh, empowerment is a strategy to strengthen women's capacity in order to make strategic life 
choices in the social environment where they were previously marginalized, and improve their capacity to make choices once they have power.

Empowerment, according to Kabeer, could be viewed in three dimensions: resources, agency, and achievement. There are three types of resource, namely (a) economic resources like land, money, capital, and other valuables; (b) human resources such as knowledge, skills, imagination, creativity, initiative; and (c) social resources is the ability to file objections, obligations, relationships, etc. The social resource is vital for the marginalized groups to balance their opportunity in life [14][15].

The second dimension is the agency, which has various definitions. In general, agency is often interpreted as the capacity of the act. To Kabeer [14], agency is someone's ability to define goals and efforts to act towards that goal. Agency could be meaning, motivation, and goal of the individual's act. Moreover, the agency could also mean decisionmaking processes such as bargaining, negotiating, cheating, manipulation, subversion, and resistance.

Next, achievement is the result of efforts done or as the end form of empowerment process, it normally relates to the development of agency and its consequences. For instance, the achievement of a successful empowerment movement for women's SMEs is the improvement in their income. However, it is better to measure the achievement by the improvement in women independence, freedom, and confidence [15]. Achievements also connect to the ability to 'access information, make decisions, and act in their interests, or the interests of those who depend on them.

In conclusion, empowerment is the improvement in capacity to make choices, in which contains three dimensions: resources as a basic condition on how the choice is made, agency in the act of choicemaking, and achievements or results from these choices. The three are interconnected because a change in one affects outcome in others.

\section{SPKP SAMO-SAMO: WORKING ON ENVIRONMENT INSPIRED BY WASTE}

SPKP Samo-Samo was established by Mahariyah, as a result of endorsement by the National Park management in 2006. This institution aimed to develop people's awareness of the environmental problems and to encourage society to solve those problems. Majority of its members are women, in which they are housewives, while only little are men.

At the time, women barely ever had the opportunity to hold a decision-making position. However, during the chairman selection, the local male leaders (in RT or RW level) were having training in Puncak area ${ }^{1}$. The training was held in Puncak led to a mistrust of these men. As a result, women obtained power and authority of leading positions at the local level.

Not much was done by SPKB early in its establishment because the SPKP management had no inspiration for activities to impact the community. In 2007, Mahariayah worked with the Center for Community Learning Activities (PKGM), with a budget supported by the Ministry of Education, to organize a sewing course for one month. The number of participants reached 20 people, from Panggang Island and Pramuka Island.

In 2009 when Kepulauan Seribu began to gain attention as a tourist destination, Mahariah was inspired to focus activities on the environment. At the time, waste management became one of her interests. Notably, Pramuka Island became a leading tourist destination since 2009 and gained various positive impacts: a) the increase in income due to locals developing homestays, b) a variety of job opportunities as a guide, snorkeling equipments rentals, boat rentals, food stalls, etc. On the negative side, the change in the local's lifestyle, high immoral behaviors, high in drug use, and drinking among teenagers, and ultimately, lack of waste management causing environmental damage (Interview with Gadis, in Kelapa Dua Island). "More than 3 tons of waste a week", said Mahariyah, especially the damaged ocean ecosystem such as coral reefs.

Initially, Mahariyah as a teacher in Islamic elementary school located on Panggang Island did not have any skills related to waste management. However, due to her strong determination to manage the environment, Mahariyah then learned autodidactly from books she intentionally bought. Since that time, Mahariyah approached 20 sewing participants in the training to process plastic waste into handicraft materials such as pencil case, bag, handphone place, prayer mat, and others; but they refused. They repeatedly questioned her, "Are these handicrafts ever going to sell?" For them, it was

1 Puncak is well-known as an area of prostititution and marriage contracts. 
better to sew pre-ordered clothes rather than making crafts from waste materials that required marketing. Mahariyah's experience indicates creativity of a woman actor who is aware of adverse impacts caused by ignoring waste problems.

Mahariyah had never been hopeless. With her friend's assistance, she began to learn sewing and started making handicrafts out of plastic waste. She got plenty of plastic waste from her students who studied Koran verses at her house. Every night, each student was required to bring at least one piece of plastic garbage. The recycled bag was given to the students. After that, following the overproduction problem, Mahariyah thought about where else could she distribute her work. Mahariyah always explored strategies to promote her environmental ideas to the community.

Fortunately, Mahariyah met with Femke den Haas, the owner, and manager of Jakarta Animal Aid Network (JAAN). The institution is specialized for the conservation of endangered species, such as turtles, dolphins, brahminy kite, and others. The meeting with Femke brought together a deal, the orang pulo (what indigenous call themselves) made a variety of handicrafts and souvenirs from plastic waste and Femke supported in marketing to her networks in Europe. Furthermore, Femke also voluntarily brought instructors to train the SPKP Samo-Samo members. Also, Femke helped them build a small hub, named Rumah Hjau (Green House), to host their daily activities.

SPKP Samo-Samo conduct various activities, among others: (a) forming activity groups namely recycling group, and green house group, each having different goals and activities. (b) building a garden house as the center of all activities, (c) making plastic waste into handicrafts, (c) learning and practicing how to make the bio pore holes, (d) making hydroponics, (d) collecting waste and waste bank on a regular basis, (e) cultivating catfish and carper fish, and (f) setting up a rabbit farm.

At the time, Mahariyah was disappointed with the work of local government that tend only to blame the people of Jakarta mainland, rather than finding solutions to issues orang pulo face every day. Mahariyah thought if we could resolve our own problems, then other issues could also be resolved together.

\section{MEASURING SPKP SAMO-SAMO AND WOMEN'S ECONOMIC EMPOWERMENT}

Kabeer's view of the three dimensions of empowerment, namely resources, agency, and achievement is used to analyze how successful SPKP Samo-Samo in empowering women in Pramuka Island and its surroundings.

\section{Developing Economic, Social and Human resources}

SPKP Samo-Samo delivers activities to develop economic resources, social resources, and human resources, in which all three are interrelated. Various activities are conducted by SPKP Samo-Samo to increase resources of communities in Kepulauan Seribu, especially in Pramuka Island and Panggang Island. Transfer of knowledge related to the impact of waste on the environment and how waste management is efficient for the community's life becomes the first knowledge socialized to the members of SPKP and the community. Then followed by a sewing skills course, this activity is essential so that women can recycle the waste into handicraft items.

Free sewing courses and sewing machine credit seems to be some of the main attractions for women in Pramuka Island and Panggang Island to participate in SPKP Samo-Samo activities actively. Later, some members studied sewing autodidact, but sewing machines as their capital were obtained through credit from SPKP Samo-Samo or even from Mahariyah's own personal funds. Meanwhile, to leverage the member's ability to imagine and encourage initiative, Mahariah, as the chairman of SPKP Samo-Samo always discuss the craft models that will be made and do some tryout before finally being promoted to the broader community. Above others, with offering credits for the sewing machine, the members also obtain financial literacy in order to manage their income and repay the loan.

The improvement in human resources is closely linked to the improvement in economic resources as well as social resources. Artificial handicrafts made by members of SPKP Samo-Samo from plastic waste are then sold. More consumers come from tourists and environmentalists alike both inside and outside the country than consumers from the surrounding community. The members income from these activities is recognized in vary by the members depending on their persistence and productivity. One member, Sahariyah said at least she earned Rp 500,000 or at most $\mathrm{Rp} 1,500,000$ per month from recycling. 
Meanwhile, social resources have also been strengthened in SPKP Samo-Samo. Notably, some of the members have been participating in various external activities either by NGO or government. Internally, during weekly meetings, members are motivated to express their own opinions and make their voices heard - which also indicates another social resource: trust, as they are willing to share their private lives amongst the organizational members. In this way, members are drawn to have the courage, independence, and capacity to speak in the public space.

During the FGD, most members of the SPKP Samo-Samo felt the significant benefits from their involvement in the institution in human resource development, economic resources, and social resources. Cici, one member, acknowledged that as she joined the group, she has developed her environmental knowledge, family expenditure began to diminish as her hydroponic garden plant was successful, her leadership skills grew and public speaking skills increased.

\section{Developing Personal Agency}

Kabeer [13] explains that agency is a person's ability to define his goals and efforts to act upon those goals. Agency can be the meaning, motivation, and purpose of the individual action. In addition, agency also includes decision-making processes such as bargaining, negotiating, cheating, manipulation, subversion, and resistance. Furthermore, agency is also a cognitive process of reflection and analysis. Therefore agency is usually associated with the power within.

SPKP members generally feel that their agency has significantly increased, especially in regards to motivation to generate their own income and no longer depend on their husbands. From the FGD of the Recycling group and the Green House participants, the following are some of their motivations:

To find activities to fill leisure time. The majority of the management and members of SPKP Samo-Samo are housewives, so on the sidelines of busy housekeeping hours, they would like to have more useful activities. This statement is in line with the explanation of a member named Yulia, "Rather than stand idle at home; I could earn at least some income here."

(2) Want to help husband make a living. Most members of SPKP Samo-Samo are fishermen's wives who are economically disadvantaged. Poverty is their main motivation in following SPKP Samo-Samo activities.

(3) Want to earn some income regardless of the small amount.

(4) Looking for work that pays without being tied too tight working hours. Sariyah, another member, has five children, so her time is filled taking care of her household. Therefore, she needs some activities to do at home when she has free time.

The SPKP Samo-samo members have not entirely completed their agency development, especially in decision-making. Most of them still need to receive their husband's approval if they would like to work or take a decision on important issues in the household. In general, they ask for husband permission about their active involvement in the organization. The efforts to build their confidence and decision-making have long been done by the SPKP's management through member's involvement in the activities, either as committee positions or determining activities. "Every program and policy is usually discussed together to build joint responsibility," Mahariyah said.

Furthermore, Mahariyah provided an example that on Earth Day celebration in April 2015, one of SPKP Samo-Samo program is to create an artificial flower garden in the pier area. The process of making these flowers through a joint experiment, which failed numerous times but eventually the flowers was successfully made from plastic waste and visible to all locals and tourists.

\section{Economic Independence, Leadership Skills,} and Networks: the Greatest Achievements

Achievement is another dimension in measuring the success of empowerment. According to Kabeer, achievement includes self-reliance, freedom, selfconfidence, access to information, decision making, and others [15]. However, this paper only focuses on the achievements of SPKP Samo-samo members in improving economic independence, sounding opinion in the public sphere, and increasing leadership skills.

Economic dependence is one of the local customs maintained by communities in Kepulauan Seribu. For instance, we found two or three families living together in one house. "People here do not have any independence. Everything depends on their parents, even though they already married", said Yulia. The lack of independence is also stated by Sunia in 
Panggang Island who always receive financial aid from her parents. Some of Samo-Samo members began to change their attitude from economic dependence towards economic independence by earning some income. Sariyah, for example, states that she wants to work, so she does not have to depend economically on her husband nor parents.

Similarly, Cici another member also feels many changes in her attitudes after becoming members of the Samo-Samo. As a chair of the "Green House Group," she acknowledges that her abilities in organizing programs, leading meeting, and speaking at public events are getting better. In fact, she was one of the least people in Kepulauan Seribu who dared to demand and criticize the local government officials under the Governor of Basuki Cahaya Purnama's Pramuka Island in 2016 issue, which is later known as the case of "Ahok Religious Blasphemy."

Cici criticizes the local government for several reasons, (a) the local government does not focus on the negative effects to the environment, (b) the lack of traditional markets in Kepulauan Seribu, (c) their activities in planting hydrophonic have no appreciation, and (d) the limited number of agricultural experts who can provide solutions

Over ten years, SPKP Samo-samo still actively exists and has grown bigger than ever. SPKP has grown a network with various stakeholders, among others (1) Internasional institutions such as CNOOC (China National Offshore Oil Corporation), Toyota Foundation, JAAN, and so on. (2) The local institutions, such as the local government of Kepulauan Seribu, Variabel Bebas Organization working in environmental issues, UIN Jakarta Theater, and Dompet Dhuafa, a charity institution. Such collaboration varies in the form: financial, technical, expertise, or training for capacity building. These network is actually the best achievement.

\section{CONCLUSION}

SPKP Samo-samo has succeeded in empowering women to improve their economic, social, and human resources. Their personality has been changing in economic independence, decision making, organizing programs, leading meetings, and speaking at public events. This finding supports the Kabeer's concept of women empowerment, which comes from resources, agency, and achievement. However, the strong networking has become an ultimate factor in the organizational development. Without strong networking, it would be impossible to survive until now. This networking aspect has not explored much in the Kabeer's concept of empowerment. 


\section{References}

[1] Ahmed, M., Siar, S.V., Wilson, D.C., Muir, J., 2006. Governance and Institutional Changes in FisheriesImpact on Poverty Reduction and Environmental Integrity in Developing Countries. Discussion Series, 3. World Fish Center, Penang, Malaysia.

[2] Zohra, Fatma, 2008, Social Economic Empowerment Strategy of Fisherman Based on Housewife Community in Pusong Baru Village, Banda Sakti District, Lhokseumawe City (Strategi Pemberdayaan Ekonomi Sosial Masyarakat Nelayan Berbasis Komunitas Ibu Rumah Tangga Di Desa Pusong Baru Village Baru Kecamatan, Banda Sakti Kota Lhokseumawe, Thesis, North Sumatera University, Medan.

[3] Kartika, Dwi Indah, 2009. Women Empowerment through Micro Credit Grameen Bank System at Jatiragas Independent Business Partner: A Case Study in Three Villages: Barugbug, Situdam and Jatiwangi, Jatisari Sub-district, Karawang District, West Java (Pemberdayaan Perempuan melalui Kredit Mikro Sistem Grameen Bank oleh Koperasi Mitra Usaha Mandiri Cabang Jatiragas (Studi Kasus di 3 Desa: Barugbug, Situdam dan Jatiwangi, Kecamatan Jatisari, Kabupaten Karawang, Jawa Barat), Tesis.

[4] Neliyanti, Heriyano Meizi, (Maret, 2013), Evaluating Community Economic Empowerment Programs in Coastal Society, Evaluasi Program Pemberdayaan Ekonomi Masyarakat Pesisir, Jurnal Kebijakan Publik, Vol. IV, No 1, h. 111-118.

[5] Hastuti, 2014. The Role of Women in Poverty Alleviation in Sleman Tourism Village, Daerah Istimewa Yogyakarta (Peran Perempuan Dalam Pengentasan Kemiskinan Di Desa Wisata Gabugan,Sleman, Daerah Istimewa Yogyakarta), Socio jurnal Ilmu Sosial), September 2014, Vol. 11, No. 2, 151-162.

[6] Widodo, Slamet, Hendri Bustamam, dan Soengkono, (April 2011), Model of Women's Economic Empowerment of Poor Fisherman Family through Effective Integrated Technology: A Study of Fishermen Family in Pondok Kelapa Districs, North Bengkulu Regency (Model Pemberdayaan Ekonomi Perempuan Keluarga Nelayan Miskin Melalui Penerapan Teknologi Tepat Guna Terpadu: Studi Keluarga Nelayan Di Kecamatan Pondok Kelapa, Kabupaten Bengkulu Utara, Jurnal Ekonomi, Tahun XXI, No. 1.
[7] Rosyidah, Ida, Murdiyah Hayati, dan Tien Romatin, (2012), Women Contribution in Economic Independence of Fishermen Family in Kepulauan Seribu (Kontribusi Perempuan dalam Kemandirian Ekonomi Keluarga Nelayan di Kepulauan Seribu). Jakarta: PSW UIN Jakarta dan Direktur Perguruan tinggi Islam Kementrian Agama RI.

[8] Anonimous. 2007. Improving The Quality Of Women's Lives: The State Policy On Improving Women's Economic Productivities (Peningkatan kualitas hidup perempuan, Kebijakan peningkatan produktivitas ekonomi perempuan (PPEP), Jakarta: Sekter Deputi Kelautan.

[9] Khairati, T. Nazlah, (2005), "Efforts to Increase Women's Participation in Fishermen's Development Program: Case Study in Meskom Village, Bengkalis Sub-district, Bengkalis Regency, Riau (Upaya Peningkatan Partisipasi Perempuan Dalam Program Pengembangan Masyarakat Nelayan: Studi Kasus Di Desa Meskom, Kecamatan Bengkalis, Kabupaten Bengkalis, Riau). Tesis. Institut Pertanian Bogor.

[10]Lincoln, Nicola Denham, Travers, Cheryl, Ackers, Peter, Wilkinson, Adrian, 2002. The Meaning of Empowerment: The Interdisciplinary Etymology of a New Management Concept, International Journal of Management Reviews, 2002.

[11]Rappaport, J., 1987. Terms of Empowerment/Exemplars Of Prevention: Toward a Theory For Community Psychology. American Journal of Community Psychology 1-1, 71-94.

[12]Eyben, R. et al. 2008. Thinking about Change for Development Practice: a Case Study from Oxfam GB, Development in Practice 18, 2: 201-212.

[13]Kabeer. October 2000, Social Exclusion, Poverty and Discrimination Towards an Analytical Framework, IDS Buletin, Volume 31, Issue 4.

[14]Kabeer, Naila, 1999, Resources, Agency, Achievements: Refections on the Measurement of Women's Empowerment, Development and Change Vol. 30, 435464.

[15]Kabeer 2005, Gender equality and women's empowerment: a critical analysis of the third Millennium Development Goal, Gender and Development Vol. 13, No. 1, March 2005, 12-24 


\section{ORIGINAL REFERENCES SEBELUM DIEDIT}

References:

Ahmed, M., Siar, S.V., Wilson, D.C., Muir, J., 2006. Governance and Institutional Changes in Fisheries-Impact on Poverty Reduction and Environmental Integrity in Developing Countries. Discussion Series, 3. World Fish Center, Penang, Malaysia.

Anonimous. 2007. Improving The Quality Of Women's Lives: The State Policy On Improving Women's Economic Productivities (Peningkatan kualitas hidup perempuan, Kebijakan peningkatan produktivitas ekonomi perempuan (PPEP), Jakarta: Sekter Deputi Kelautan.

Eyben, R. et al. 2008. Thinking about Change for Development Practice: a Case Study from Oxfam GB, Development in Practice 18, 2: 201-212.

Figure of Kepulauan Seribu in 2016 (Kabupaten Kepulauan Seribu dalam Angka 2016), Central Bureau of Statistics of Kepulauan Seribu Regency

Figure of DKI Jakarta in 2017 (DKI Jakarta dalam Angka 2017), Central Bureau of Statistics of DKI Jakarta.

Hastuti, 2014. The Role of Women in Poverty Alleviation in Sleman Tourism Village, Daerah Istimewa Yogyakarta (Peran Perempuan Dalam Pengentasan Kemiskinan Di Desa Wisata Gabugan,Sleman, Daerah Istimewa Yogyakarta), Socio jurnal Ilmu Sosial), September 2014, Vol. 11, No. 2, 151-162.

Lincoln, Nicola Denham, Travers, Cheryl, Ackers, Peter, Wilkinson, Adrian, The meaning of Empowerment: The Interdisciplinary Etymology of a New Management Concept, International Journal of Management Reviews, 2002.

Kartika, Dwi Indah, 2009. Women Empowerment through Micro Credit Grameen Bank System at Jatiragas Independent Business Partner: A Case Study in Three Villages: Barugbug, Situdam and Jatiwangi, Jatisari Sub-district, Karawang District, West Java (Pemberdayaan Perempuan melalui Kredit Mikro Sistem Grameen Bank oleh Koperasi Mitra Usaha Mandiri Cabang Jatiragas (Studi Kasus di 3 Desa: Barugbug, Situdam dan Jatiwangi, Kecamatan Jatisari, Kabupaten Karawang, Jawa Barat), Tesis.

Kabeer 2005, Gender equality and women's empowerment: a critical analysis of the third Millennium Development Goal, Gender and Development Vol. 13, No. 1, March 2005, 12-24

Kabeer, Naila, 1999, Resources, Agency, Achievements: Refections on the Measurement of Women's Empowerment, Development and Change Vol. 30, 435-464.
Kabeer. October 2000, Social Exclusion, Poverty and Discrimination Towards an Analytical Framework, IDS Buletin, Volume 31, Issue 4.

Khairati, T. Nazlah, (2005), "Efforts to Increase Women's Participation in Fishermen's Development Program: Case Study in Meskom Village, Bengkalis Subdistrict, Bengkalis Regency, Riau (Upaya Peningkatan Partisipasi Perempuan Dalam Program Pengembangan Masyarakat Nelayan: Studi Kasus Di Desa Meskom, Kecamatan Bengkalis, Kabupaten Bengkalis, Riau). Tesis. Institut Pertanian Bogor.

Lincoln, Nicola Denham, Travers, Cheryl, Ackers, Peter, Wilkinson, Adrian, 2002. The Meaning of Empowerment: The Interdisciplinary Etymology of a New Management Concept, International Journal of Management Reviews, 2002.

Neliyanti, Heriyano Meizi, (Maret, 2013), Evaluating Community Economic Empowerment Programs in Coastal Society, Evaluasi Program Pemberdayaan Ekonomi Masyarakat Pesisir, Jurnal Kebijakan Publik, Vol. IV, No 1, h. 111-118.

Rappaport, J., 1987. Terms of Empowerment/Exemplars Of Prevention: Toward a Theory For Community Psychology. American Journal of Community Psychology 1-1, 71-94.

Rosyidah, Ida, Murdiyah Hayati, dan Tien Romatin, (2012), Women Contribution in Economic Independence of Fishermen Family in Kepulauan Seribu (Kontribusi Perempuan dalam Kemandirian Ekonomi Keluarga Nelayan di Kepulauan Seribu). Jakarta: PSW UIN Jakarta dan Direktur Perguruan tinggi Islam Kementrian Agama RI.

Setyawati. Th Any, (2008), "The Role of Coastal Women Activities in the Improvement of Family Economics in Tangerang Regency (Peran Aktivitas Perempuan Pesisir Dalam Peningkatan Ekonomi Keluarga di Kabupaten Tangerang". Thesis. Institut Pertanian Bogor.

Widodo, Slamet, Hendri Bustamam, dan Soengkono, (April 2011), Model of Women's Economic Empowerment of Poor Fisherman Family through Effective Integrated Technology: A Study of Fishermen Family in Pondok Kelapa Districs, North Bengkulu Regency (Model Pemberdayaan Ekonomi Perempuan Keluarga Nelayan Miskin Melalui Penerapan Teknologi Tepat Guna Terpadu: Studi Keluarga Nelayan Di Kecamatan Pondok Kelapa, Kabupaten Bengkulu Utara, Jurnal Ekonomi, Tahun XXI, No. 1.

Zohra, Fatma, 2008, Social Economic Empowerment Strategy of Fisherman Based on Housewife Community in Pusong Baru Village, Banda Sakti 
District, Lhokseumawe City (Strategi Pemberdayaan Ekonomi Sosial Masyarakat Nelayan Berbasis Komunitas Ibu Rumah Tangga Di Desa Pusong Baru Village Baru Kecamatan, Banda Sakti Kota Lhokseumawe, Thesis, North Sumatera University, Medan. 